\title{
CORRESPONDENCE
}

\section{UPPER EUMORPHOCERAS BEDS ON BENBRACK, COUNTY CAVAN.}

SIR,-Eumorphoceras bisulcatum Girty has been collected from the shales at the summit of Benbrack $(1,648 \mathrm{ft}$.), the mountain south of Cuilcagh $\left(2,188 \mathrm{ft}\right.$.). These beds, of $\mathrm{E}_{2}$ age, are therefore the youngest beds yet recorded in this large North Central Irish Millstone Grit outlier. Due to the comparatively flat block-faulted structure of the outlier the youngest beds occur on the hill-tops, but Padget (1953, p. 25) states that no diagnostic fossils of the $E_{2}$ stage were found on Cuilcagh, where his described succession ends well below the summit.

Dr. F. Hodson informs me that the highest beds on Dough Mountain and Black Mountain in the north-west of the outlier do not range into the $E_{2}$ stage. According to the Geological Survey of Ireland one-inch map (Sheet 56) higher beds than those on Benbrack outcrop to the south-west on Bencroy and might be expected eventually to yield goniatites of higher level, though it seems unlikely that any true Westphalian Coal Measures occur there as indicated on the Geological Survey map.

The specimen has been deposited in the Geological Survey Museum, London (No. 95317).

Geology Department,

IMPERJAC COLLEGE, LONDON, S.W.7.

6 th December, 1955.

Patricia J. Yates.

\section{REFERENCE}

Padget, P., 1953. The Stratigraphy of Cuilcagh. Geol. Mag., xc, 17-26.

\section{NOTICE}

\section{ZOOLOGICAL NOMENCLATURE}

Notice is hereby given that the possible use by the International Commission on Zoological Nomenclature of its Plenary Powers is involved in applications relating to the undermentioned names included in Part 9 of Volume 11 of the Bulletin of Zoological Nomenclature, published on 30th December, 1955.

(1) Phillipsinella Novák, 1886.(Class Trilobita), validation of (Z.N.(S.)757).

(2) Seguenziceratidae Spath (L.F.), 1924 (Class Cephalopoda, Order Ammonoidea), suppression of (Z.N.(S.)931),

Any specialist who may desire to comment on any of the foregoing applications is invited to do so in writing to the Secretary to the International Commission (Address : 28 Park Village East, Regent's Park, London, N.W. 1, England) as soon as possible. Every such comment should be clearly marked with the Commission's File Number as given in the present notice.

If received in sufficient time before the commencement of voting by the International Commission on the applications in question, comments received in response to the present notice will be published in the Bulletin of Zoological Nomenclature ; comments received too late for publication will be brought to the attention of the International Commission at the time when voting commences on the application in question. 